\title{
Protection of mice by a pseudodiffuse strain of Staphylococcus aureus possessing polyvalent capsular type antigen
}

\author{
M. CHOMARAT, Y. ICHIMAN* and K. YOSHIDA* $\dagger$
}

Laboratoire de Bactériologie, Centre Hospitalier Lyon-Sud, F 69310 Pierre-Benite, Lyon, France, and "Department of Microbiology. St Marianna University School of Medicine, 2-16-1, Sugao, Miyamae-ku, Kawasaki 213, Japan

\begin{abstract}
Summary. Staphylococcus aureus strain MC31 showed pseudodiffuse growth in serumsoft agar and reacted with immune rabbit sera to strains Smith diffuse (capsular type A), NS58D (type B) and NS41D (type C) but not with strain NS68D (type D) in serum-soft agar. Immunisation of mice with $300 \mu \mathrm{g}$ of cell-surface polysaccharide extracted from strain MC31 protected against lethal infection by strain MC31 and the strains of capsular types A, B and C. Immune rabbit serum prepared against strain MC31 passively protected mice against challenge infection with the homologous strain, but approximately 30 times more anti-MC31 serum was required to protect against infection with the strains of capsular types A, B and C. Absorption of the passive protective activity of immune sera raised against the three capsular type strains required at least 10 times the quantity of MC31 cell-surface polysaccharide than the quantity of cell-surface polysaccharide from the homologous capsular strain. Electronmicrographs of strain MC31 treated with ferritin-labelled antisera to the three capsular strains showed only small amounts of ferritin granules around the cell wall.
\end{abstract}

\section{Introduction}

Staphylococcus aureus strains exhibiting compact growth in serum-soft agar (SSA) are known to be non-capsulate (Koenig, 1962). Recently, we designated strains that produced diffuse colonies in regular SSA but compact growth in alkaline SSA (pH 8.4) as "pseudodiffuse"(Chomarat et al., 1985). Electronmicroscopy showed these strains to be noncapsulate. Yoshida $(1971,1972)$ differentiated $S$. aureus capsules serologically into four types-A, $\mathrm{B}, \mathrm{C}$ and D. In the present study, strain MC31, isolated from a clinical specimen, was examined for reactions with anti-capsular sera, A, B, C and D. Cross-protection experiments and electronmicroscopy were used to investigate further the antigenic nature of this strain.

\section{Materials and methods}

\section{Bacteria}

$S$. aureus strain MC31 was isolated from a clinical specimen at the Bacteriology Section of the Clinical

Received 26 Jan. 1988; accepted in revised form 11 July 1988.

$\dagger$ Correspondence should be sent to Dr K. Yoshida.
Laboratory, South Lyons Central Hospital, Lyons, France. It gave positive results in tests for coagulase, DNAase, mannite fermentation, haemolysin production and clumping factor reaction, and produced compact colonies in SSA according to the method of Finkelstein and Sulkin (1958). However, this isolate showed diffusetype growth in alkaline SSA by the method described by Chomarat et al. (1985). Other $S$. aureus strains used were Smith diffuse, NS58D, NS41D and NS68D; these represented, respectively, the capsular types A, B, C and D, as defined by Yoshida $(1971,1972)$.

\section{Animals}

Animals used in the study were DD-strain conventional mice (Nihon Clea Farm, Tokyo, Japan) weighing approximately $20 \mathrm{~g}$ and female rabbits (Japanese white rabbits, Nihon Clea Farm) weighing approximately $2.5 \mathrm{~kg}$.

\section{Preparation of cell-surface polysaccharides}

Extraction of cell-surface polysaccharides was performed by a modification of the method described by Morse (1962). Strains were grown overnight in modified 110 broth (Yoshida and Ekstedt, 1968a), and inoculated on to modified 110 agar. After overnight incubation at 
$37^{\circ} \mathrm{C}$, the organisms were harvested and sonicated at 10 kilocycles for $5 \mathrm{~min}$. After centrifugation at $6000 \mathrm{~g}$ for $20 \mathrm{~min}$, supernates were treated with DNAase $10 \mu \mathrm{g} / \mathrm{ml}$ (Sigma), and RNAase $50 \mu \mathrm{g} / \mathrm{ml}$ (Sigma) in a $37^{\circ} \mathrm{C}$ water bath for $30 \mathrm{~min}$. An equal volume of chloroform was then added and the suspension was held at $4^{\circ} \mathrm{C}$ overnight while mixing with a magnetic stirrer. The water soluble layer was removed and dialysed against $0.06 \mathrm{M}$ phosphatebuffered saline (PBS, pH 7.0) overnight at $4^{\circ} \mathrm{C}$. Sodium acetate was added to a final concentration of $1 \%$, followed by 5 volumes of cold ethanol $95 \%$ and the mixture left standing overnight at $4^{\circ} \mathrm{C}$. Resultant precipitates were harvested by centrifugation, treated with ether to remove lipids, and resuspended in distilled water before being lyophilised.

\section{Immunisation of mice with cell-surface polysaccharides from strain $M C 31$}

Saline $(0.5 \mathrm{ml})$ containing $100 \mu \mathrm{g}$ or $300 \mu \mathrm{g}$ of extracted cell-surface polysaccharides was injected intraperitoneally (i.p.) into groups of five mice. Ten days later, the mice were challenged with homologous and heterologous $S$. aureus strains as described below. For the unvaccinated mice only saline was given.

\section{Challenge infection in vaccinated mice}

S. aureus strains were cultured in Brain Heart Infusion Broth (BHI, Difco) overnight at $37^{\circ} \mathrm{C}$, washed once and resuspended in saline to an optical density (OD) at $430 \mathrm{~nm}$ of 1.0 . Serial tenfold dilutions were made in sterile saline and $0.5 \mathrm{ml}$ of each dilution was mixed with $4.5 \mathrm{ml}$ of mucin (Wilson-type) $5 \%$. Groups of five mice were given i.p. injections of $0.5 \mathrm{ml}$ of these preparations representing challenge doses of $10^{7}, 10^{6}, 10^{5}$ and $10^{4} \mathrm{cfu} /$ $\mathrm{ml}$. The number of deaths during a period of 7 days was then recorded. In these experiments minimal lethal doses ( $100 \%$ kill) for the three capsular types A, B, C and strain MC31 were $10^{4}, 10^{5}, 10^{6}$ and $10^{7} \mathrm{cfu} / \mathrm{ml}$ respectively. These challenge doses were used in all the mouse protection studies.

\section{Preparation of antisera}

$S$. aureus strains were grown in BHI broth overnight at $37^{\circ} \mathrm{C}$, washed once, resuspended in saline to an OD of 1.0 and autoclaved at $121^{\circ} \mathrm{C}$ for $20 \mathrm{~min}$. During the first week, $0.5 \mathrm{ml}$ of the cell suspension was injected intravenously into rabbits on three successive days. A similar protocol was followed during the second week, but the dose was increased to $1.0 \mathrm{ml}$. At the end of the third week, serum samples were taken and antistaphylococcal antibody titres were assayed by a haemagglutination method (Yoshida and Ekstedt, 1968b). If the titres were lower than 1280 , a booster injection $(1.0 \mathrm{ml})$ was given.

\section{Passive protection of mice by immune rabbit sera}

Immune rabbit sera were diluted 1 in 3,1 in 10,1 in 30 and 1 in 100 in saline. Groups of five mice were given i.p. injections of $1 \mathrm{ml}$ or $0.5 \mathrm{ml}$ of neat serum or $0.5 \mathrm{ml}$ of diluted serum; $30 \mathrm{~min}$ later, $0.5 \mathrm{ml}$ of staphylococcal suspension (prepared in 5\% mucin, as described above) was injected i.p. The number of deaths over a period of 7 days after the challenge infection was recorded.

\section{Absorption of passive protective activity of immune rabbit sera}

Immune rabbit sera prepared against strain $\mathrm{MC} 31$, and the capsular types A, B and C were standardised to the minimal dilution which afforded protection of mice to challenge with the homologous strain (see Yoshida et al., 1987). To $1 \mathrm{ml}$ volumes of these dilutions varying amounts $(0 \cdot 3,1,3$ and $10 \mathrm{mg})$ of cell-surface polysaccharides were added. After incubation for $2 \mathrm{~h}$ at $37^{\circ} \mathrm{C}$ the suspensions were centrifuged, and $0.5 \mathrm{ml}$ of the supernates were injected i.p. into groups of five mice; $30 \mathrm{~min}$ after inoculation, mice were challenged with strains of the homologous capsular type and strain MC31. The number of deaths within 7 days after the challenge infection was recorded.

\section{Electronmicroscopic studies}

Strains grown at $37^{\circ} \mathrm{C}$ overnight in modified 110 broth were inoculated on to Staphylococcus 110 agar medium (Eiken Co., Ltd, Tokyo, Japan) and incubated for $18 \mathrm{~h}$ at $37^{\circ} \mathrm{C}$. The organisms were harvested, gently washed once with saline and then fixed in glutaraldehyde $2.5 \%$ in $0.06 \mathrm{M}$ phosphate buffer, $\mathrm{pH} 7 \cdot 2$. After washing twice with saline, the suspensions were dehydrated in ethanol and embedded in Epon-812 by standard procedures. Ultra-thin sections were prepared and stained with ferritin-labelled antibody raised against strain MC31 or one of the three capsular types A, B or C (Yoshida and Minegishi, 1976). Preparations treated with normal rabbit serum were used as controls. Sections were examined in a Model 100-B electronmicroscope (Japan Electron Optics Lab., Tokyo, Japan).

\section{Results}

\section{Colonial morphologies of strain MC31 in SSA}

Strain MC31 showed compact type growth in SSA (pH 7.2) containing antisera raised in rabbits against strain MC31 or one of the strains of capsular types A, B or C (fig. 1). However, strain MC31 showed diffuse growth in SSA containing anti-D capsular antiserum. These findings suggested the production of the capsular type antigens, A, B and $\mathrm{C}$ in strain MC31. 


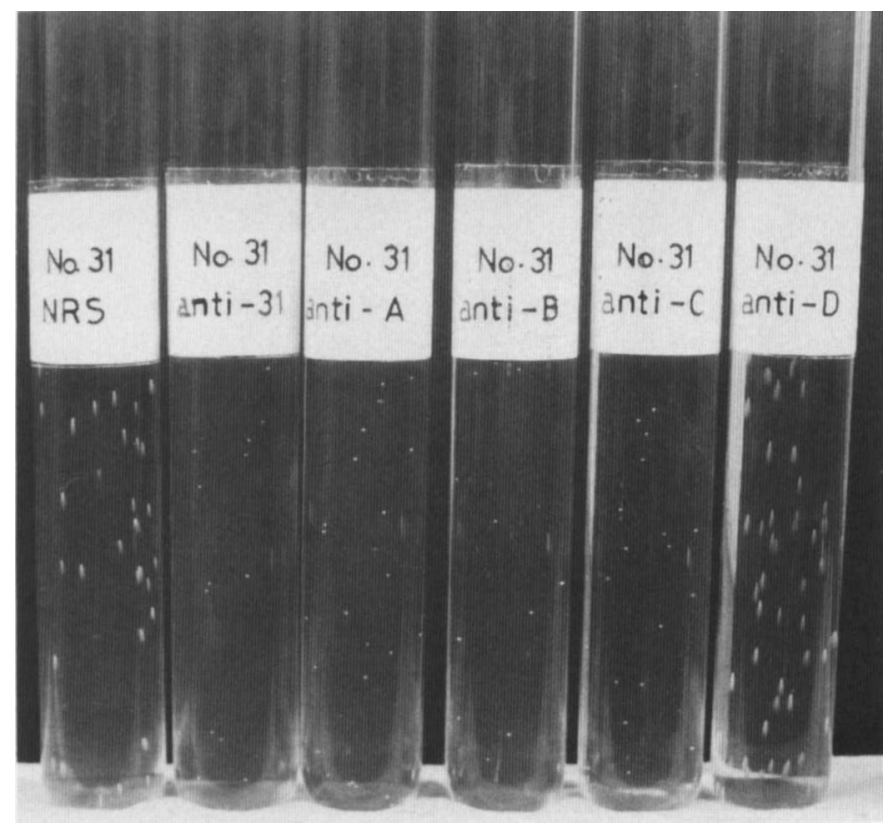

Fig. 1. Colonial morphologies of strain MC31 of S. aureus in regular SSA containing normal rabbit serum (NRS), immune rabbit serum raised against strain MC31 (anti-31), or against each of the four capsular types of $S$. aureus (A-D).

Protection of mice by active immunisation with MC31 cell-surface polysaccharide

Immunisation with $300 \mu \mathrm{g}$ of the MC31 cellsurface polysaccharide protected all mice in challenge infections with strains MC31 or the capsular types $\mathrm{A}$ and $\mathrm{C}$ (table 1), and four out of five mice challenged with the capsular type B strain. Immunisation with $100 \mu \mathrm{g}$ of MC31 polysaccharide did not protect against challenge with any of the four strains.

\section{Passive protection of mice with anti-MC31 rabbit serum}

The specificity of passive protection by antiMC31 rabbit serum was tested in mice by challenge infection with homologous and heterologous strains. Mice were protected against challenge by strain MC31 with $0.5 \mathrm{ml}$ of a 1 in 10 dilution antiMC31 rabbit serum (table II). However, $1.0 \mathrm{ml}$ of neat anti-MC31 serum was required to protect against challenge with strains of the capsular types A, B or C.

\section{Absorption of passive protective activity of rabbit} immune serum with purified cell-surface polysaccharides

To investigate further the specificity of immune rabbit sera, absorption studies were performed with
Table I. Challenge infection of mice immunised with MC31 surface polysaccharide

\begin{tabular}{l|cccc}
\hline & $\begin{array}{l}\text { Number of mice dead/total on day 7 after } \\
\text { challenge with } S \text {. aureus (dose, cfu/ml) }\end{array}$ \\
\cline { 2 - 5 } $\begin{array}{c}\text { MC31 surface } \\
\text { polysaccharide } \\
\text { dose/mouse }\end{array}$ & $\begin{array}{c}\text { Capsule } \\
\text { type A } \\
\left(10^{4}\right)\end{array}$ & $\begin{array}{c}\text { Capsule } \\
\text { type B } \\
\left(10^{5}\right)\end{array}$ & $\begin{array}{c}\text { Capsule } \\
\text { type C } \\
\left(10^{6}\right)\end{array}$ & $\begin{array}{c}\mathrm{MC31} \\
\left(10^{7}\right)\end{array}$ \\
\hline $100 \mu \mathrm{g}$ & $5 / 5$ & $5 / 5$ & $5 / 5$ & $5 / 5$ \\
$300 \mu \mathrm{g}$ & $0 / 5$ & $1 / 5$ & $0 / 5$ & $0 / 5$ \\
saline & $4 / 5$ & $5 / 5$ & $5 / 5$ & $5 / 5$ \\
\hline
\end{tabular}

purified cell-surface polysaccharides. For antiMC31 serum, protective activity against challenge infection with the homologous strain was completely absorbed with $1.0 \mathrm{mg}$ of MC31 cell-surface polysaccharide (table III). Absorption of the protective activities of rabbit anti-A, anti-B and anti$C$ immune sera was achieved with $\leq 1 \mathrm{mg}$ of homologous cell-surface polysaccharide but $10 \mathrm{mg}$ of MC31 cell-surface polysaccharide was required to achieve the same effect (table III).

\section{Electronmicroscopy studies of strain MC31}

Ultra-thin sections of strain MC31 were treated with ferritin-labelled antisera prepared against 

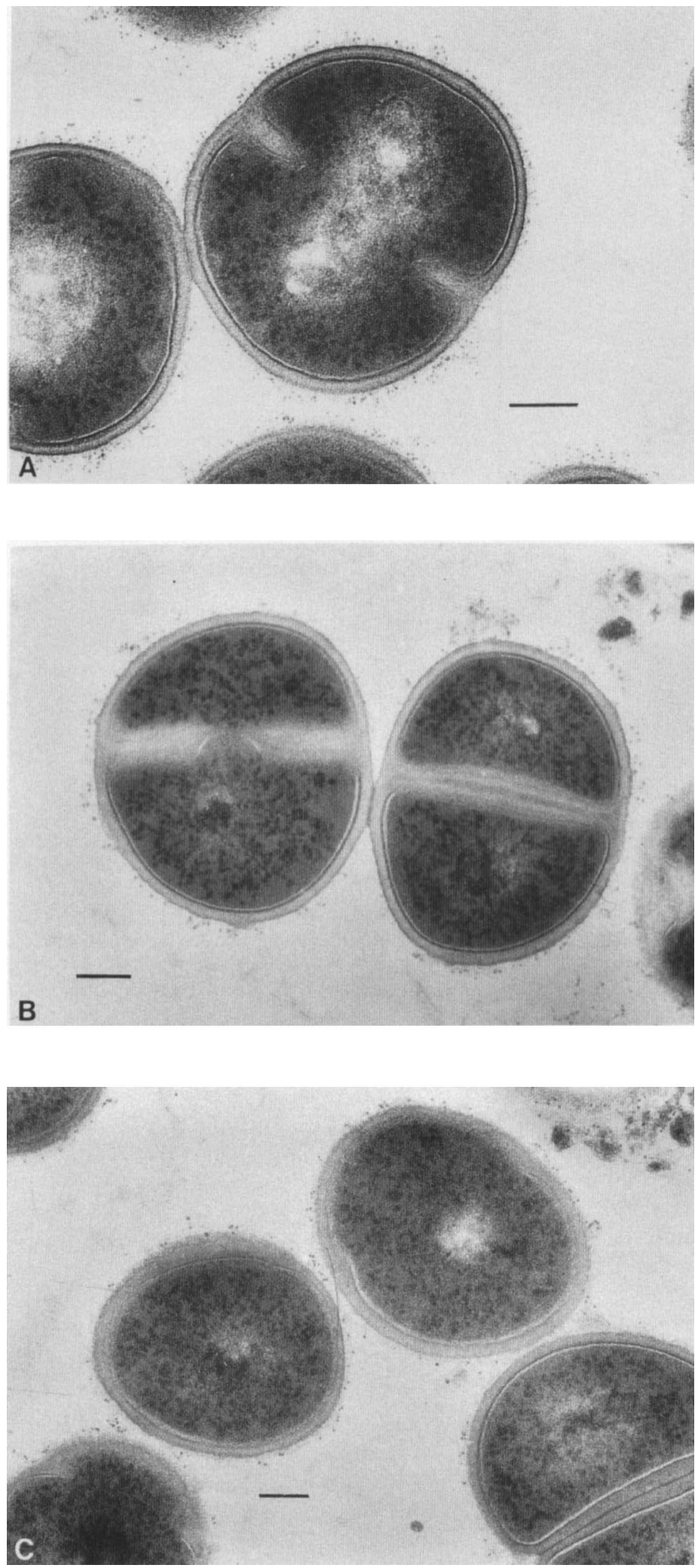

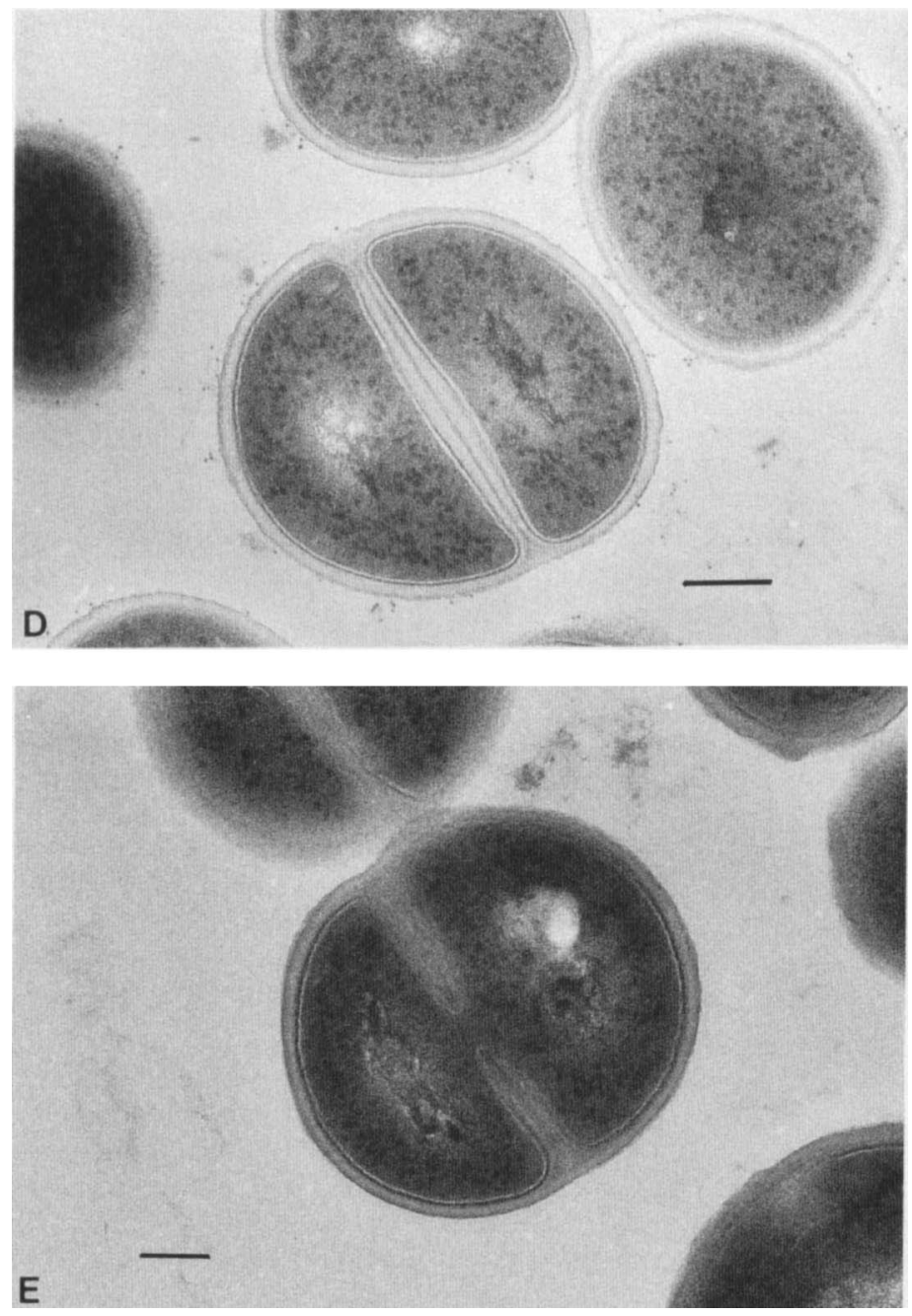

Fig. 2. Electronmicrographs of $S$. aureus strain MC31 treated with ferritin-labelled immune rabbit sera-(A) anti-MC31, (B) anti$\mathrm{A},(\mathbf{C})$ anti-B, (D) anti-C or (E) normal rabbit serum; bars $=0 \cdot 1 \mu \mathrm{m}$.

strains MC31, or the three capsular types A, B and C. Small numbers of ferritin granules were observed around the outer layer of the cell wall of the organisms treated with all four antisera (fig. 2AD). However, sections of strain MC31 treated with normal rabbit serum showed no evidence of a capsule (fig. 2E). In contrast, sections of the capsule type A strain treated with ferritin-conjugated homologous antiserum showed that the cell wall was surrounded by numerous ferritin granules embedded in amorphous material (fig. 3).

\section{Discussion}

Although the role of the capsule in infection with and immunity to $S$. aureus is well established (Hunt and Moses, 1958; Rogers, 1962; Ekstedt, 1965; Wilkinson, 1983) definitions of capsules vary. Yoshida and Minegishi (1976) proposed the following criteria for defining capsulate strains-negative clumping factor reaction, diffuse type growth in SSA and non-typable by serology and phages. However, Wilkinson (1983) noted the following characteristics of $S$. aureus capsules-visible by negative staining under the light microscope, diffuse-type growth in SSA, phage non-typable and mouse-lethal. Karakawa and Wann (1982) identified $S$. aureus capsules by detecting capsular polysaccharide but Wilkinson (1983) suggested these capsules should be regarded as micro-capsules and commented that the significance of large capsules and micro-capsules in the pathogenesis of 
Table II. Passive protection of mice by immune rabbit serum to strain MC31

\begin{tabular}{l|cccc}
\hline & $\begin{array}{c}\text { Number of mice dead/total on day } 7 \text { after } \\
\text { challenge with } S \text {. aureus strain (dose, } \\
\text { cfu/ml) }\end{array}$ \\
$\begin{array}{l}\text { Dilution and } \\
\text { dose of } \\
\text { anti-MC31 } \\
\text { serum }\end{array}$ & $\begin{array}{c}\text { Capsule } \\
\text { type A } \\
\left(10^{4}\right)\end{array}$ & $\begin{array}{c}\text { Capsule } \\
\text { type B } \\
\left(10^{5}\right)\end{array}$ & $\begin{array}{c}\text { Capsule } \\
\text { type C } \\
\left(10^{6}\right)\end{array}$ & $\begin{array}{c}\mathrm{MC} 31 \\
\left(10^{7}\right)\end{array}$ \\
\hline neat $(1.0 \mathrm{ml})$ & $0 / 5$ & $0 / 5$ & $0 / 5$ & $\mathrm{ND}$ \\
neat $(0.5 \mathrm{ml})$ & $3 / 9$ & $7 / 9$ & $2 / 9$ & $0 / 5$ \\
$1: 3(0.5 \mathrm{ml})$ & $5 / 5$ & $5 / 5$ & $5 / 5$ & $0 / 5$ \\
$1: 10(0.5 \mathrm{ml})$ & $\mathrm{ND}$ & $\mathrm{ND}$ & $\mathrm{ND}$ & $0 / 5$ \\
$1: 30(0.5 \mathrm{ml})$ & $\mathrm{ND}$ & $\mathrm{ND}$ & $\mathrm{ND}$ & $5 / 5$ \\
saline & $7 / 9$ & $9 / 9$ & $8 / 9$ & $5 / 5$ \\
& \multicolumn{4}{c}{} \\
\hline
\end{tabular}

$\mathrm{ND}=$ not done

Table III. Absorption of immune rabbit sera by cellsurface polysaccharide

\begin{tabular}{l|lc}
\hline & \multicolumn{1}{|c}{$\begin{array}{c}\text { Absorbed with } \\
\text { cell-surface } \\
\text { polysaccharide }\end{array}$} & $\begin{array}{c}\text { Amount required } \\
\text { for total absorption } \\
\text { Antiserum }\end{array}$ \\
\hline Anti MC31 & MC31 & 1.0 \\
Anti A & MC31 & 10.0 \\
Anti B & capsular type A & 0.3 \\
Anti C & MC31 & 10.0 \\
& capsular type B & 0.3 \\
& MC31 & 10.0 \\
& capsular type C & 1.0 \\
\hline
\end{tabular}

infections by $S$. aureus may be quite different. Protection against capsulate strains of $S$. aureus has been shown to be type-specific when capsular types were determined by the SSA technique (Yoshida, 1981). Protection studies with capsular types defined by other methods (Maverakis and Wiley, 1969; Karakawa and Wann, 1982) have not been performed.

Strain MC31 showed diffuse-type growth in regular SSA, but compact-type growth in alkali SSA (pseudodiffuse) and no capsule could be demonstrated by electronmicroscopy. Nevertheless, the strain reacted with rabbit antisera to the representative strains of capsular types A, B and C, indicating the production of capsular polysaccharides.

Early in-vivo studies suggested non-capsulate strains of $S$. aureus were unable to induce protection (Koenig et al., 1962; Ekstedt, 1965). However, Ekstedt and Yoshida (1969) demonstrated protection of mice with the Smith compact strain (noncapsulate) against challenge infection with the
Smith diffuse strain (capsulate). Yoshida et al. (1975) also observed the establishment of protection by either active or passive immunisation with large amounts of heat-killed non-capsulate strains against lethal infection with the Smith diffuse strain. The protection-inducing antigen has been shown to be a cell-surface polysaccharide (Morse, 1962; Fisher et al., 1963; Yoshida et al., 1987). In the present work active immunisation with $300 \mu \mathrm{g}$ of cellsurface polysaccharide of strain MC31 protected against challenge infection not only by the homologous strain but also by the strains of capsular types A, B and C. A lower dose of $100 \mu \mathrm{g}$ did not protect against any of the challenge strains. In previous work (Yoshida et al., 1987), only $3 \mu \mathrm{g}$ of cell-surface polysaccharide from capsulate strains was required to protect against infection with the homologous capsulate strain.

Passive protection of mice against challenge infection with strains of capsular types $\mathrm{A}, \mathrm{B}$ or $\mathrm{C}$ required approximately 20 times the amount of anti-MC31 rabbit serum that protected against infection with the homologous strain. Furthermore, complete absorption of the protective activity of the anti-capsular immune sera required 10-30 times more cell-surface polysaccharide from strain MC31 than from the homologous capsular type strain. All of these findings suggest that significantly smaller amounts of protection-inducing antigens were contained within cell-surface polysaccharide of strain MC31 than those of representative single capsular type strains. These results were paralleled by the electronmicroscopy findings which indicated that the MC31 strain possessed the three capsular polysaccharides on its surface but that the amounts of each were small.

Opdebeek and Norcross (1983) regarded those $S$. aureus strains showing diffuse type growth in modified 110 SSA as capsulate and, adhering to this definition, showed that $93 \%$ of fresh isolates of these strains had capsules. However, determination of capsulation only by growth type in modified 110 SSA would include the pseudodiffuse-type strains which are non-capsulate. Employing capsulartyping sera, Sompolinski et al. (1985) showed that $90 \%$ of fresh isolates of $S$. aureus were capsulate; however, these were assumed not to be the large capsules as noted above. Previously, Yoshida et al. (1970) reported only $37(4 \cdot 2 \%)$ capsulate strains among 875 isolates from human clinical specimens based on their criteria for capsulation. These contrasting reports suggest that the majority of $S$. aureus strains do not produce large capsules but that some strains may possess micro-capsules or produce small quantities of capsular substances. A 


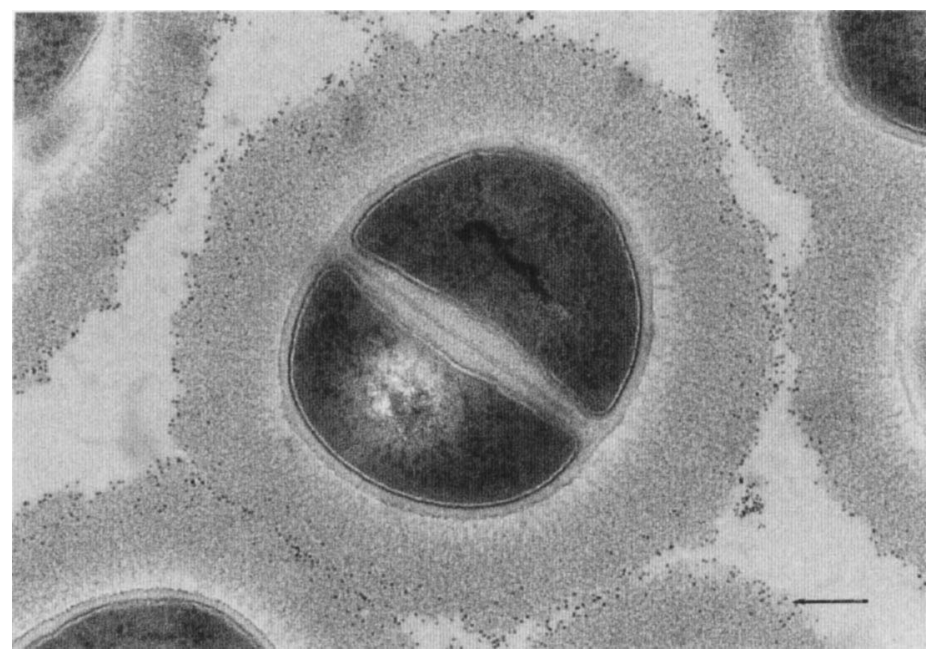

Fig. 3. Electronmicrographs of $S$. aureus strain Smith diffuse treated with ferritin-labelled immune rabbit serum raised against the homologous strain; bars $=0 \cdot 1 \mu \mathrm{m}$.

high frequency of polyvalent capsular-type strains has been found among non-capsulate strains isolated from clinical specimens (Yoshida et al., 1979).
S. aureus strains similar to strain MC31 may be widely distributed in the natural environment and infection with these organisms may be common.

\section{REFERENCES}

Chomarat M, Ichiman Y, Yoshida K 1985 Pseudodiffuse-type growth of a Staphylococcus aureus strain in serum-soft agar. Journal of Clinical Microbiology 22: 132-133.

Ekstedt R D 1965 Mechanisms of resistance to staphylococcal infection: natural and acquired. Annals of the New York Academy of Science 128: 301-334.

Ekstedt R D, Yoshida K 1969 Immunity to staphylococcal infection in mice: effect of living versus killed vaccine, role of circulating antibody, and induction of protectioninducing antigens in vitro. Journal of Bacteriology 100: 745750.

Finkelstein R A, Sulkin S E 1958 Characteristics of coagulase positive and coagulase negative staphylococci in serum-soft agar. Journal of Bacteriology 75 : 339-344.

Fisher M W, Devlin H B, Erlandson A L 1963 A new staphylococcal antigen. Its preparation and immunizing activity against experimental infections. Nature 199: 10741075.

Hunt G A, Moses A J 1958 Acute infection of mice with Smith strain of Staphylococcus aureus. Science 128: 1574-1575.

Karakawa W W, Wann W F 1982 Capsular polysaccharides of Staphylococcus aureus. Seminars in Infectious Diseases 4: 285-293.

Koenig M G 1962 Factors relating to the virulence of staphylococci. I. Comparative studies on two colonial variants. Yale Journal of Biology and Medicine 34 : 537-559.

Koenig M G, Melly M A, Rogers R E 1962 Factors relating to the virulence of staphylococci. III. Antibacterial versus antitoxic immunity. Journal of Experimental Medicine 116: $60 \mathrm{l}-610$

Maverakis N H, Wiley B B 1969 Evidence for a multiplicity of capsular types among Staphylococcus aureus strains. Journal of Bacteriology 99 : 472-479.
Morse S I 1962 Isolation and properties of a surface antigen of Staphylococcus aureus. Journal of Experimental Medicine 115: 295-311.

Opdebeek J P, Norcross N L 1983 Frequency and immunologic cross-reactivity of encapsulated Staphylococcus aureus in bovine milk in New York. American Journal of Veterinary Research 44: 986-988.

Rogers D E 1962 Staphylococci and man. Journal of the American Medical Association 181 : 38-40.

Sompolinski D, Samara Z, Karakawa W W, Vann W F, Schneerson R, Malik Z 1985 Encapsulation and capsular types in isolates of Staphylococcus aureus from different sources and relationship to phage types. Journal of Clinical Microbiology 22: 828-834.

Wilkinson B J 1983 Staphylococcal capsules and slime. In: Easmon C S F, Adlam C (eds) Staphylococci and staphylococcal infections, vol. 2. Academic Press, Inc., London, pp 481-523.

Yoshida K 1971 Demonstration of serologically different capsular types among strains of Staphylococcus aureus by the serum-soft agar technique. Infection and Immunity 3 : 535-539.

Yoshida K 1972 Isolation of an additional capsular-type strain of Staphylococcus aureus by the serum-soft agar technique. Infection and Immunity 5: 833-834.

Yoshida K 1981 Relation of capsular-type of strains of Staphylococcus aureus to the protection-inducing activity. The St Marianna Medical Journal 4: 327-333.

Yoshida K, Ekstedt R D 1968 a Relation of mucoid growth of Staphylococcus aureus to clumping factor reaction, morphology in serum-soft agar, and virulence. Journal of Bacteriology 96 : 902-908.

Yoshida K, Ekstedt R D 1968 b Antibody response to Staphylococcus aureus in rabbits: Sequence of immunoglobulin 
synthesis and its correlation with passive protection in mice. Journal of Bacteriology 96: 1540-1545.

Yoshida K, Minegishi Y 1976 Capsular substance production in unencapsulated strains of Staphylococcus aureus. In: Jeljaszewitz J (ed) Staphylococci and staphylococcal Diseases. Gustav Fisher Verlag, Stuttgart, pp 359-375.

Yoshida K, Ichiman Y, Ohtomo T 1975 Induction of resistance with heat-killed compact-type strains of Staphylococcus aureus against challenge with the diffuse variant of the Smith strain of Staphylococcus aureus. Infection and Immunity 12: 939-942.
Yoshida K, Smith M R, Naito Y 1970 Biological and immunological properties of encapsulated strains of Staphylococcus aureus from human sources. Infection and Immunity 2: 528-532.

Yoshida K et al. 1979 Application of fuorescent antibody for detecting capsular substances in Staphylococcus aureus. Journal of Applied Bacteriology 46: 147-152.

Yoshida K, Umeda A, Ohshima Y 1987 Induction of resistance in mice by the capsular polysaccharide antigens of Staphylococcus aureus. Microbiology and Immunology 31 : 649-656. 